\title{
Effect of incubation temperature on the development of lactic acid bacteria and their phages
}

\author{
By TOMASO SOZZI, J.MARC POULIN AND ROGER MARET \\ Department of Technological Development, Nestle Products \\ Technical Assistance Co. Ltd, Lausanne, Switzerland
}

(Received 20 May 1977)

SUMmary. Thirty-one strains of mesophilic and thermophilic lactic acid bacteria and their respective phages were tested for their minimum, optimum and maximum multiplication temperatures. Culture growth was strongly influenced by temperature during the first few hours of incubation, but less so after $24 \mathrm{~h}$. Most of the phages showed the same pattern of development as their hosts, but one phage lysing a thermophilic lactobacillus and 3 phages lysing mesophilic streptococci proved temperature-sensitive, having a lower maximum temperature than that of their hosts. One phage was unusual in that its minimum development temperature was $7^{\circ} \mathrm{C}$ above that of its host. Differences in temperature sensitivity were insufficient to reduce risk of phage infection by temperature control in industrial processes.

Certain bacteriophages are unable to multiply at temperatures at which their host bacteria still grow actively. This characteristic is widely used for studies of microbial genetics and especially those concerned with phages of certain strains of Escherichia coli (Epstein et al. 1963; Spiegelmann et al. 1968) and Bacillus subtilis (Hemphill \& Whiteley, 1975).

A similar phenomenon may sometimes be observed with the lactic acid bacteria. For instance, certain wild-type bacteriophages of Streptococcus cremoris do not develop at $37^{\circ} \mathrm{C}$ although their host grows well at this temperature (Hunter, 1943; Zehren \& Whitehead, 1954). Temperature-sensitive phages of both Leuconostoc mesenteroïdes (Kaneko, Iwano \& Kitahara, 1955) and Lactobacillus casei (Murata, 1971) have also been isolated. The latter is not replicated above $40^{\circ} \mathrm{C}$ although its host, which has an optimum growth temperature of $37-41{ }^{\circ} \mathrm{C}$, grows well at $43-44{ }^{\circ} \mathrm{C}$.

Recently Keogh (1973), in a study on the latent period and burst size of 19 phages tested at 30 and $37^{\circ} \mathrm{C}$ found that for 6 of them, no phage was produced at $37^{\circ} \mathrm{C}$ while a burst size of $2-50$ was observed at $30^{\circ} \mathrm{C}$.

The aim of our study was to improve our knowledge of lactic acid bacteria and their phages and to see whether production losses caused by phages in the dairy industry could be prevented by careful choice of incubation temperatures. 
Table 1. Origin of the strains tested

Organisms

Streptococcus cremoris

Str. lactis

Str. diacetylactis

Str. thermophilus

Lactobacillus bulgaricus

L. helveticus

L. lactis
Strains

C13, BK5, Z8, P2, E8, TR, H2

Z8(2), HP, ML1, C11

11, Lille, Sa1, 264, 274, 280

ML3

26.2

$\$ 265, \mathrm{~L} 12, \mathrm{S133}$

440

19987

448,449

$\mathrm{L} 112$

450

A, F1

15808
Obtained from*

Pearce, NZDRI

Keogh, CSIRO

Sozzi, LINOR

Galloway, WSAC

Sandine, OSU

Sozzi, LTNOR

Accoles, INRA

Kiuru-Tybeck, ATCC

Accolas, INRA

Sozzi, LINOR

Accolas, INRA

Sozzi, LINOR

Kiuru-Tybeck, ATCC

* NZDRI, New Zealand Dairy Research Institute; CSIRO, Commonwealth Scientific and Industrial Research Organisation, Australia; LINOR, Laboratoire Industriel Nestlé, Orbe, Switzerland; WSAC, West of Scotland Agricultural College, Dept. of Dairy Technology; OSU, Oregon State University, Dept. of Microbiology, U.S.A.; INRA, Institut National de la Recherche Agronomique, Jouy-en-Josas, France; ATCC, American Type Culture Collection.

\section{MATERLALS AND ME'THODS}

Phages and host bacteria. These are listed in Table 1. The taxonomic name Str. lactis subsp. diacetylactis will hereafter be abbreviated to Str. diacetylactis.

Maintenance of cultures. The strains and their phages were transferred and stored using the routine method described previously (Sozzi, 1972).

Culture media. The following 2 media were used: MRS broth (de Man, Rogosa \& Sharpe, 1960) for the lactobacilli; Hogg \& Jago's (1970) medium for the streptococci.

Temperature gradient. The temperature gradients were obtained by means of an apparatus of our own construction, 'Graditherm', based on Oppenheimer's principle (Oppenheimer \& Drost-Hansen, 1960). It provides a linear gradient of 25 temperatures for up to 6 different samples (i.e. 150 tubes in all), with a stability better than $0.2^{\circ} \mathrm{C} / 24 \mathrm{~h}$ and $\pm 0.15^{\circ} \mathrm{C}$ fluctuations (after a 4-h equilibration time).

A gradient from 7 to $55^{\circ} \mathrm{C}\left(\Delta T=2{ }^{\circ} \mathrm{C}\right)$ for mesophiles and from 20 to $56{ }^{\circ} \mathrm{C}$ $\left(\Delta T=1.5^{\circ} \mathrm{C}\right)$ for thermophiles was used.

Experimental technique. The tubes containing the medium $(10 \mathrm{ml})$ were placed in the Graditherm at least $4 \mathrm{~h}$ before inoculation to allow temperature to stabilize. Each tube was inoculated $(1 \%$ ) with a 6 -h culture of the test strain and cultured in the same medium, at $30^{\circ} \mathrm{C}$ for mesophiles and $40^{\circ} \mathrm{C}$ for thermophiles. Two series of tubes were inoculated for each strain, the first with the bacterial strain only, the second with the strain and its phage. After careful mixing the tubes were incubated in the Graditherm for $6 \mathrm{~h}$. The growth in each tube was then determined by measuring the optical density of the suspension at $540 \mathrm{~nm}$ in a Spectronic 20 spectrophotometer (Baush and Lomb, 14625-Rochester N.Y. U.S.A.). In cases of slow growth, this determination was repeated after $24-\mathrm{h}$ incubation.

Phage count. The phages were estimated by counting the plaques obtained by the double layer technique of Sozzi, Maret \& Poulin (1976). The samples used for 
(a)

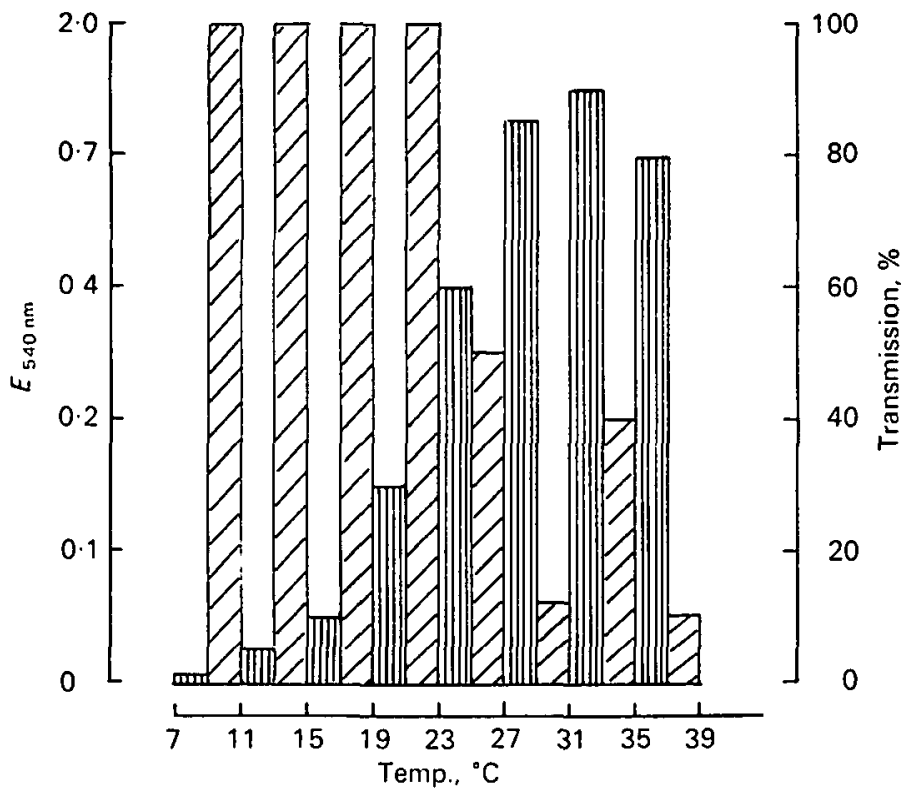

(b)

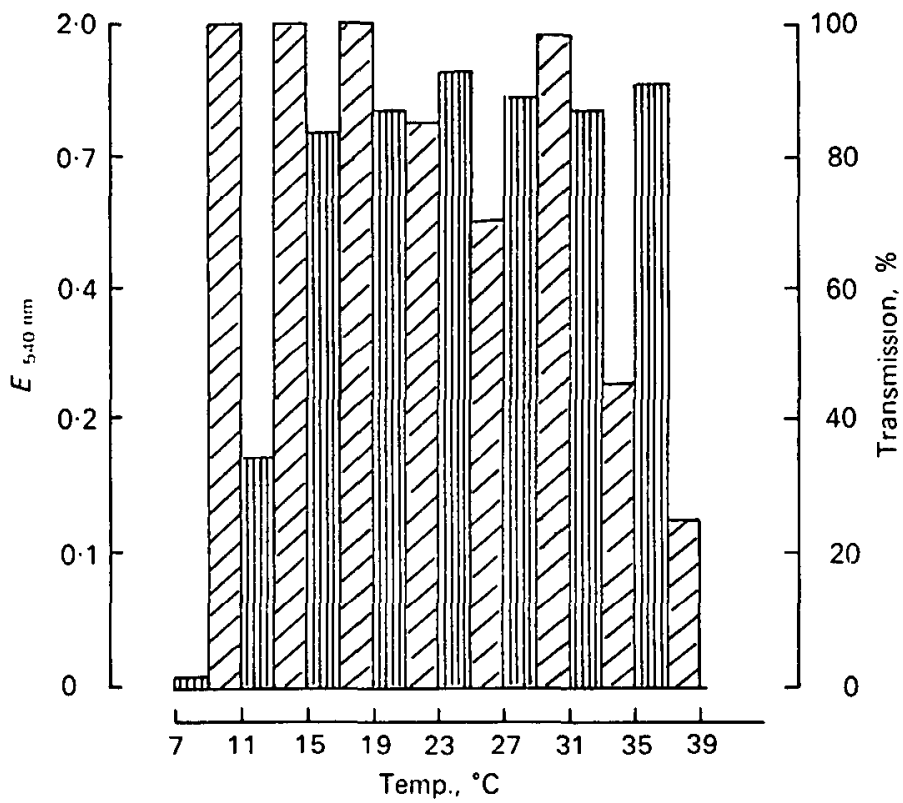

Fig. 1. Effect of incubation temperature on the growth of Streptococcus cremoris CSIRO C 11 and its phage. In a temperature gradient: (a) $6 \cdot \mathrm{h}$ incubation; (b) 24-h incubation. $\mathrm{W}$, Absorbance $540 \mathrm{~nm}$ phage free host; $凤$, transmission phage infected host. 

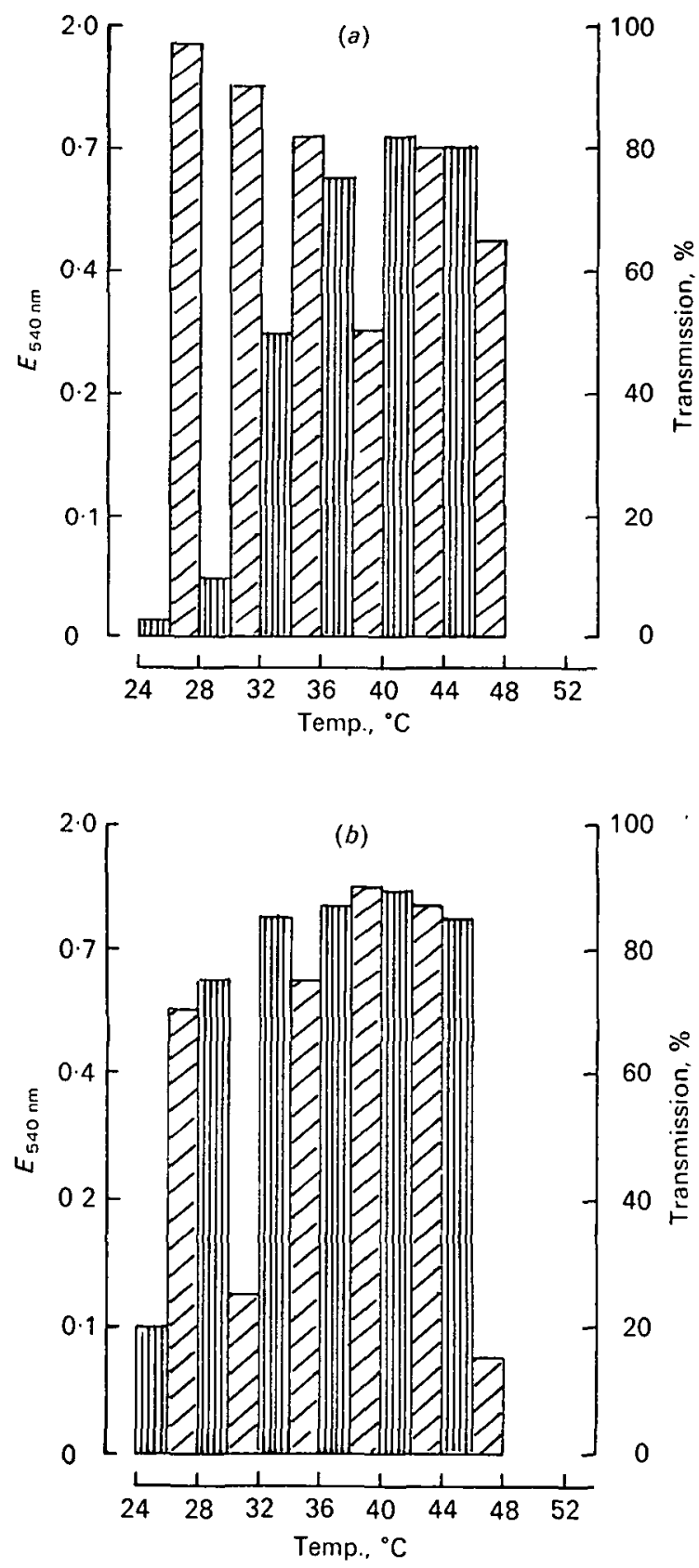

Fig. 2. Effect of inoubation temperature on the growth of Streptococcus thermophilus ATCC 19987 and its phage. In a temperature gradient: (a) 6.h incubation; (b) 24-h incubation. 四 Absorbance $540 \mathrm{~nm}$ phage free host; $囚$, transmission phage infected host. 
Table 2. Minimum, optimum and maximum growth temperatures for the host bacteria and their bacteriophages

\begin{tabular}{|c|c|c|c|c|c|c|c|c|}
\hline \multirow{3}{*}{$\begin{array}{l}\text { Taxonomy, } \\
\text { no. of strains }\end{array}$} & \multirow{3}{*}{$\begin{array}{c}\text { No. of } \\
\text { phages* }\end{array}$} & \multicolumn{6}{|c|}{ Temp. ${ }^{\circ} \mathrm{C}$, average values } & \multirow{3}{*}{$\begin{array}{c}\text { Cases of } \\
\text { thermo- } \\
\text { sensi- } \\
\text { tivity }\end{array}$} \\
\hline & & \multicolumn{3}{|c|}{ Bacteria } & \multicolumn{3}{|c|}{ Phages } & \\
\hline & & Min. & Opt. & Max. & $\overparen{\text { Min. }}$ & $\overbrace{\text { Opt. }}$ & Max. & \\
\hline $\begin{array}{l}\text { Streptococcus } \\
\text { cremoris (11) }\end{array}$ & 11 & $11 \pm 2$ & $30 \pm 3$ & $35 \pm 3$ & $11 \pm 2$ & $30 \pm 3$ & $35 \pm 3$ & 0 \\
\hline Str. lactis (7) & 11 & $9 \pm 1$ & $34+1$ & $41 \pm 2$ & $9 \pm 1$ & $33+2$ & $41 \pm 2$ & 2 \\
\hline Str. diacetylactis (1) & 1 & 9 & 33 & 37 & 9 & 29 & 33 & 1 \\
\hline Str. thermophilus (5) & 5 & $21-23$ & $39-41$ & $46-47$ & $21-23$ & $39-40$ & $46-47$ & 0 \\
\hline $\begin{array}{l}\text { Lactobacillus } \\
\quad \text { bulgaricus (2) }\end{array}$ & 2 & $29-32$ & $42-43$ & $49-50$ & $29-32$ & $42-43$ & $49-50$ & 0 \\
\hline L. helveticus (2) & 2 & $23-28$ & $44-45$ & $55-50$ & $30-28$ & $38-45$ & $50-50$ & 1 \\
\hline L. lactis (3) & 3 & $26-29$ & $43-45$ & $50-51$ & $26-29$ & $43-45$ & $50-51$ & 0 \\
\hline
\end{tabular}

* Each bacterial strain had 1 specific phage except Str. lactis 274, which was the host for 5 phages.

Table 3. Minimum, optimum and maximum temperatures of multiplication of some temperature-sensitive phages and their hosts

Host and phage
Streptococcus lactis 274
Phage 21
Str. lactis 280
Phage 280
Str. diacetylactis 26-2
Phage 26-2
Lactobacillus helveticus L 112
Phage 1112

\begin{tabular}{ccc}
\multicolumn{3}{c}{ Temp., ${ }^{\circ} \mathrm{C}$} \\
Min. & Opt. & Mex. \\
9 & 33 & 41 \\
9 & 33 & $\mathbf{3 7}$ \\
9 & $\mathbf{3 3}$ & $\mathbf{4 1}$ \\
9 & 33 & 35 \\
9 & 33 & 37 \\
9 & 29 & 33 \\
23 & $\mathbf{4 4}$ & 55 \\
30 & 38 & 50
\end{tabular}

estimating the number of phages were withdrawn with those for the first spectrophotometric reading, i.e. after $6 \mathrm{~h}$ of incubation.

\section{RESULTS}

The effect of temperature on the growth of the microorganisms after 6 and $24 \mathrm{~h}$ of incubation is shown in Figs 1 and 2. Bacterial growth was strongly influenced by temperature in the first few hours of incubation (Figs $1 a$ and $2 a$ ). However, after $24 \mathrm{~h}$, this effect diminished considerably and the precise optimum temperature was replaced by a range of temperatures permitting maximum growth (Figs $1 b$ and $2 b$ ).

The multiplication of the phages followed almost the same pattern as that of the host strain. The maximum degree of bacterial lysis is attained after $24 \mathrm{~h}$ of incubation, but in some cases the bacterial culture was well clarified after $6 \mathrm{~h}$ and dense again after $24 \mathrm{~h}$ (Fig. $1,31-35^{\circ} \mathrm{C}$, Fig. $2,44-48^{\circ} \mathrm{C}$ ). This is a secondary culture of the host, no doubt due to the proliferation of phage-resistant mutants. This secondary growth was generally greatest close to the optimum temperature of the host strain.

The minimum, optimum and maximum temperatures for development of phages and their host bacteria are grouped in Table 2. The parallel between the phages and 


\section{Table 4. Behaviour of the phages of mesophilic streptococci incubated for $6 \mathrm{~h}$ at different temperatures}

\begin{tabular}{|c|c|c|c|c|c|c|c|c|}
\hline \multirow[b]{3}{*}{ Phages of } & \multirow{3}{*}{$\begin{array}{c}\text { Approx. } \\
\text { conon } \\
\text { (pfu/ml) }\end{array}$} & \multicolumn{7}{|c|}{ No. of phage cultures } \\
\hline & & \multirow[b]{2}{*}{ Initial } & \multicolumn{6}{|c|}{ After $6 \mathrm{~h}$ incubation at ${ }^{\circ} \mathrm{C}$} \\
\hline & & & 7 & 17 & 27 & 37 & 47 & 55 \\
\hline \multirow{6}{*}{$\begin{array}{l}\text { Streptococcus cremoris } \\
\text { (11 strains) }\end{array}$} & $10^{8}$ & - & - & - & 3 & - & - & - \\
\hline & $10^{7}$ & - & - & 8 & 6 & 2 & - & - \\
\hline & $10^{6}$ & 5 & 4 & 2 & 2 & 1 & 1 & 1 \\
\hline & $10^{5}$ & 4 & 5 & 1 & - & 4 & 5 & 4 \\
\hline & $10^{4}$ & 2 & 1 & - & 一 & 4 & 3 & 3 \\
\hline & $10^{3}$ & - & 1 & - & - & - & 2 & 3 \\
\hline \multirow{6}{*}{$\begin{array}{l}\text { Str. lactis and } \\
\text { diacetylactis } \\
\text { (12 strains) }\end{array}$} & $10^{8}$ & - & - & - & 6 & 4 & 一 & - \\
\hline & $10^{7}$ & - & - & 8 & 5 & $\mathbf{3}$ & 一 & - \\
\hline & $10^{\circ}$ & 4 & 5 & 2 & 1 & 4 & - & - \\
\hline & $10^{3}$ & 4 & 4 & 2 & - & 1 & 10 & \\
\hline & $10^{4}$ & 4 & 3 & 二 & - & 二 & 2 & 6 \\
\hline & $10^{3}$ & - & 一 & - & 一 & 一 & 一 & 1 \\
\hline
\end{tabular}

(Distribution of the cultures according to their approximate concentration in $\mathrm{pfu} / \mathrm{ml}$.)

their hosts is evident and there are very few temperature-sensitive phages. In general, the bacteriophages multiplied whenever the bacteria grew.

Table 3 shows in more detail the differences between the 4 temperature-sensitive phages which we found. All of them differed from their hosts in maximum temperature, but one only in minimum temperature, and two in optimum temperature.

To supplement the photometric measurements, we estimated the rate of phage multiplication after $6 \mathrm{~h}$ of incubation at different temperatures using the plaque count method. The results are grouped in Table 4. Each strain was tested for the number of active phages at the time of inoculation, and after $6 \mathrm{~h}$ of incubation at 6 different temperatures. The Table shows, for each temperature, the number of cultures containing the concentration of phages $(\mathrm{pfu} / \mathrm{ml})$ indicated in the margin.

These results are in agreement with those obtained photometrically, and it is interesting to note that the phages are not killed by exposure at $55^{\circ} \mathrm{C}$ for $6 \mathrm{~h}$ : their multiplication is blocked, but their numbers are not reduced.

\section{DISCUSSION}

In this study we have only used short incubation times -6 and $24 \mathrm{~h}$ - to investigate the effect of temperature on the growth of phages and their host bacteria. Although the results may be of little interest to taxonomists, who generally work with much longer incubation periods, they should be valuable to the food industry, for in any fermentation process the quality of the end-product is greatly dependent on what happens in the first few hours of fermentation. This is illustrated by the temperature profiles which we obtained. Indeed, although quite a wide range of temperatures favour growth after $24 \mathrm{~h}$ incubation, after only $6 \mathrm{~h}$ incubation there is a precise optimum temperature and deviations from this may cause serious delays in growth. The importance of strictly controlling the optimum temperature for 
development of lactic acid bacteria is thus obvious, especially during the milk coagulation process in cheese production.

The knowledge acquired from this study may be valuable for the future preparation of starters and especially mixed cultures. Attention must be paid to the fact that the optimum temperature is very near to the maximum one, above which bacterial growth decreases extremely rapidly. Thus, temperature regulation cannot be used to prevent phage attacks because, with few exceptions, the phages exhibit the same temperature curves as their hosts.

We are grateful to $\mathrm{Mr} \mathrm{O}$. Depierraz for his excellent technical assistance and to Miss A. Walker for her help in writing this paper in English.

\section{REFERENCES}

de Man, J. C., Rogosa, M. \& Sharpe, M. E. (1960). Journal of Applied Bacteriology 23, 130.

Epsten, R. H., Bolle, A., Stennberg, C. M., Kellengerger, E., Boy de la Tour, E., Chevalley, R., Edgar, R. S., Susman, M., Denhardt, G. H. \& Limlausis, A. (1963). Cold Spring Harbor Symposia on Quantitative Biology 28, 375.

HEMPнIL, H. E. \& WHITELEY, H. R. (1975). Bacteriological Reviews 39, 257.

Hoag, D. MoC. \& JAGO, G. R. (1970). Journal of Dairy Research 37, 199.

HuNTER, G. J. E. (1943). Journal of Dairy Research 13, 136.

Kaneko, T., Iwano, S. \& KITahaRa, K. (1955). Journal Agricultural Chemical Society of Japan $29,788$.

KEOGH, B. P. (1973). Journal of Dairy Research 40, 303.

Murata, A. (1971). Agricultural and Biological Chemistry 35, 667.

OPPENHEIMER, C. H. \& DROST-HLANSEN, W. (1960). Jourmal of Bacteriology 80, 21.

Sozzi, T. (1972). Lait 52, 454.

Sozzi, T., Maret, R. \& PouLIs, J. M. (1976). Applied and Environmental Microbiology $32,131$.

Spieghiman, S., PaOe, N. R., Milis, D. R., Levisohn, R., Elkhom, T. S., Taylor, M. M., Peterson

R. L. \& BrsHor, D. H. L. (1968). Cold Spring Harbor Symposia on Quantitative Biology 33, 101.

ZEHREN, V. L. \& WhTTEHEAD, H. R. (1954). Journal of Dairy Science 37, 209. 